\title{
Fetal Central Nervous System and Infectious Diseases
}

\author{
${ }^{1}$ Lucia Masini, ${ }^{2}$ Massimo Apicella, ${ }^{3}$ Carmen De Luca, ${ }^{4}$ Piero Valentini, ${ }^{5}$ Riccardo Manfredi \\ ${ }^{6}$ Antonio Lanzone, ${ }^{7}$ Marco De Santis
}

\section{ABSTRACT}

Maternal infectious diseases are frequent complications of pregnancy and can cause negative outcomes. Perinatal infections can cause serious damage to fetal central nervous system (CNS), but incidence of symptomatic congenital infections at birth is low. Complete and multidisciplinary (obstetric, infectologist, microbiologist, neonatologist/pediatrician, psychologist) evaluation of the pregnant women is crucial to define fetal prognosis. The ultrasound (US) surveillance has an irreplaceable role in identifying serious fetal damage and complications. Complete evaluation of the fetus in selected cases needs to be integrated with invasive prenatal diagnosis, particularly amniocentesis, which has optimal predictive values in excluding vertical transmission, and fetal magnetic resonance imaging (MRI), which can add important anatomical detail when fetal CNS damage is suspected. Congenital infections, furthermore, need to be considered in differential diagnosis of some common abnormal CNS findings at prenatal US. With the present review, we intend to provide an overview of the major perinatal infections and the role of US diagnosis in their assessment to recognize fetal CNS damage. We highlight the most recognizable syndromes due to congenital infections by linking etiopathogenesis with pathology and imaging. In particular, we focus on US diagnostic and prognostic values in relation to other invasive and noninvasive prenatal diagnosis options and summarize up-to-date recommendations on US evaluation of most common findings. Cytomegalovirus (CMV) is the most common cause of congenital infection, while Toxoplasmosis is the most preventable cause of infectious CNS damage; rubella, varicella virus, and herpes viruses, even if rarely, may be responsible for extremely serious fetal damage, while Zika virus is an emerging concern on global scale.

Keywords: Cytomegalovirus, Fetal magnetic resonance, Herpes simplex, Infections, Prenatal diagnosis, Rubella, Toxoplasma, Ultrasound, Varicella-zoster, Zika virus.

How to cite this article: Masini L, Apicella M, De Luca C, Valentini P, Manfredi R, Lanzone A, De Santis M. Fetal Central Nervous System and Infectious Diseases. Donald School J Ultrasound Obstet Gynecol 2017;11(4):314-327.

\footnotetext{
${ }^{1,4,7}$ Assistant Professor, ${ }^{2,3}$ Medical Doctor, ${ }^{5,6}$ Professor

1-3,6,7 Department of Woman and Child Health, Obstetrics and Neonatology Area, Università Cattolica Del Sacro Cuore, Rome Italy

${ }^{4}$ Department of Woman and Child Health, Pediatrics Area Università Cattolica Del Sacro Cuore, Rome, Italy

${ }^{5}$ Department of Radiology, Università Cattolica Del Sacro Cuore Rome, Italy
}

Corresponding Author: Lucia Masini, Assistant Professor Department of Woman and Child Health, Obstetrics and Neonatology Area, Università Cattolica Del Sacro Cuore, Rome Italy, Phone: +390630156774, e-mail: lucia.masini@unicatt.it

\section{Source of support: Nil}

Conflict of interest: None

\section{INTRODUCTION}

Maternal infectious diseases can interfere with pregnancy in different ways. Sometimes, they may not influence the course of the pregnancy, but sometimes pregnancy exacerbates maternal illness or the infectious disease causes negative pregnancy outcomes. Some viral, bacterial, parasitic, or fungal pathogens can infect the fetus by vertical transmission. In most cases, in utero infection takes places when a microorganism crosses the relatively impervious placental barrier or, to a lesser extent, the agent can infect the fetus in an ascending way from a maternal genital infection, even with intact amniochorial membranes. A few pathogens are perfectly evolved to cross any nonpermissive biologic barrier and have an impressively wide cellular tropism, but also host factors, gestational age (GA) above all, are relevant in pathogenesis. Bloodstream pathogens may set an infection of the placenta and the fetus, but the placenta can be infected and the fetus not and vice versa. In the diagnosis as well as in the pathogenesis of congenital infections, placenta has a key role and its US, pathological, and microbiological examinations have an essential value. However, it has to be kept in mind that placental infection is not always followed by and does not always precede fetal infection, contributing to the suboptimal predictability of its US evaluation. The infection of the product of conception may determine blastopathy, when it takes places before the 15th day of development, embriopathy when it takes place between the 16th and the 72nd day of development, or fetopathy when it takes place later. The possible outcomes of a pregnancy in which a vertical infection has taken place include: Embryonic death and reabsorption, abortion and stillbirth, prematurity, intrauterine growth restriction (IUGR), low birth weight, developmental abnormality and teratogenic events, or specific congenital disease. Often, an apparently healthy infected infant (asymptomatic) is delivered and may shed for a variably long time the pathogen, and never suffer from any consequence of the congenital infection or show delayed sequelae for the persistent latent infection. Long-term sequelae typically involve not only the CNS along with sensory organs, but also substantial or only 
subtle interference with the developing immune system is hypothesized or well demonstrated.

Fetal CNS is a target in most congenital diseases, because its development is not complete even at birth; the effects of their infections throughout gestation and in the first years of life may have a dramatic impact. Even when a baby is born without any clinical or instrumental sign of a resolved or ongoing encephalitis, long-term neurocognitive outcome may be affected and this is still an important field of study. Neurons and glial cells may be permissive to the infection themselves, since many microorganisms which are adapted to cross the nonpermissive placental barrier are also able to cross the blood-brain barrier. The cell infection may be lytic, followed by necrosis and inflammation of the tissue, resulting in focal disruption of areas of the parenchyma with persistent scars. It may also be latent, often implying a disturbance of the delicate process of neuron migration and synapses development. In most cases, the vascular and support structures are primarily involved, with following necrosis and inflammation, in the form of meningitis and small vessel vasculitis. Bystander damage from immune system cells is often one of the most relevant factors in pathogenesis of brain damage. Disruption of subependymal areas may lead to diffuse liquoral spreading of the microorganism and necrotic debris can interfere with liquor flow and reabsorption resulting in hydrocephalus. Even when CNS does not seem to be prominently involved, it may suffer from chronic hypoxia. Placental inflammation with villitis, endothelial necrosis, increase in Hofbauer cells, thickening of the exchange membrane, villous calcifications, perivascular cysts and, in most serious cases, placental hydrops interfere with fetal blood (FB) oxygenation. Sometimes, direct damage to the heart or to hematopoietic cells, isolated or as part of a diffuse multiorgan fetal disease, compromises cardiovascular function. Furthermore, coagulation is altered in some infections and CNS hemorrhage may be a result.

The eye is particularly subjected to many infections too. It is often contaminated by direct contact in the birth channel by some pathogens transmitted perinatally, but in case of intrauterine infection, it is invaded by bloodstream microorganisms able to cross the blood retinal barrier. Damage to ocular structures usually starts from the uveal layer. Chorioretinitis is a common finding but, depending on the degree of inflammation along with spreading of microbial and inflammatory debris in the vitreous and in the anterior chamber, all other structures, such as the lens may be secondarily affected. In severe cases, phthisis of the whole eye with microphthalmia occurs, which may be attributed to secondary atrophy or primary arrest of development. Interference with the eye development can lead also to colobomas and vestige of the pupillary membrane, sometimes reported in infections with the same pathogens which cause chorioretinitis. Optic atrophy is another serious, but rare consequence.

The inner ear is very susceptible too, and possible pathology ranges from agenesis/disgenesis/necrosis of the Corti organ to sensory neural hearing loss (SNHL) without any obvious pathological finding. Functional defects in absence of prominent necrosis or inflammation have been reported and an interference in neural networks from cochlea to eighth nerve is a current hypotheses to explain them. Inner ear involvement is very difficult to predict and detect prenatally.

The US examination is of great help in the evaluation and follow-up of pregnancies complicated by maternal infections. In some cases, US findings are the first to raise the suspicion of a congenital infection, yet they are never pathognomonic and serologic. Microbiologic or histopathologic studies on the mother, on amniotic fluid (AF), or on the fetus himself (invasive prenatal diagnosis by cord blood or chorionic villus sampling or autopsy in case of fetal demise) are needed to establish a diagnosis. Suspicious findings for an infection from a Toxoplasma, others, rubella, CMV, herpes virus (TORCH) microorganism include intracranial calcification, microcephaly, hydrocephalus, ascites, hepatosplenomegaly, and severe IUGR. The Royal College of Obstetrics and Gynaecologists guidelines, for example, recommend to screen for CMV and Toxoplasma in any case of severe IUGR, since in the United Kingdom, universal screening for these infections in pregnant women is not performed. ${ }^{1}$ Parvovirus B19 (PVB19), as well as coxsackievirus, CMV, Toxoplasma infection, or hepatitis viruses must be considered in the differential diagnosis of a fetal hydrops. More often, US findings of fetal infection are detected during the surveillance of a mother, who has already received a diagnosis of infection following a suspicious set of symptoms, a positive screening test, or specific diagnostic tests after exposure to a potential source of transmission. Typical maternal findings to investigate are mononucleosis like illnesses [possible in infection due to CMV, Toxoplasma, PVB19, primary human immunodeficiency virus (HIV) infection], rash [varicella-zoster virus (VZV), Treponema, rubella, Borrelia, measles, herpes simplex virus (HSV), PVB19], or genital lesions (HSV, Treponema, Chlamydia, Neisseria gonorrhoeae, Candida]. Screening is universally indicated for HIV, hepatitis C virus, hepatitis B virus, and Treponema pallidum infection, while Toxoplasma is screened in pregnancy in Italy, France, Austria, Belgium, and Switzerland. The CMV screening is not officially recommended in Italy, yet it is still widely practiced. It should be stressed that maternal immunoglobulin M positivity is never sufficient to establish a diagnosis of acute infection, but, as any screening test, needs to be integrated 
with history and clinical examination and confirmed with specific and complete serologic panels, virology or molecular diagnosis in a reference center. When a diagnosis of maternal infection is confirmed, strict US surveillance from an expert operator is recommended. In the absence of any fetal complication, monthly scans are appropriate in case of CMV and Toxoplasma primary infection, but surveillance needs to be intensified in case of complication possibly implying a rapid evolution. For other infections, there is no explicit recommendation on scans frequency. In case of maternal PVB19 infection, most experts agree that after 20 weeks of GA, weekly scans for 12 weeks including evaluations of middle cerebral artery (MCA) peak systolic velocity are needed to diagnose severe fetal anemia, since intrauterine fetal transfusion might be needed. In a fetus exposed to microorganism with the potential to cause a myocarditis, such as Coxsackievirus, additional scans until delivery may be needed to detect early signs of cardiovascular impairment. The US has a prognostic value in identifying specific fetal complications of the infections or nonspecific obstetric complications, but in cases in which CNS damage is strongly suspected, the prognosis may be better defined by invasive prenatal diagnosis (amniocentesis, cord blood sampling) or by second level imaging, such as fetal MRI. One of the few examples of well-studied prognostic indexes on AF or FB is congenital CMV infection, where the severity of fetal infection is roughly related to viral load on $\mathrm{AF}$, and neonatal prognosis is dependent on liver enzymes and platelet count on FB. The US diagnosis of established fetal disease may help select a subset of fetuses which may benefit from in utero therapeutic trials. In a broader perspective, US surveillance has a positive effect on the woman and her dealing with a pregnancy at risk and in the process of a multidisciplinary and complete care-taking, trying to deal with any problem in the planning of delivery, and subsequent neonatologic and pediatric follow-up, without ignoring the possible need for psychological support to the couple., ${ }^{2,3}$

The more frequent findings in congenital infections and, particularly, CNS findings are listed in Tables 1 and 2.

\section{CYTOMEGALOVIRUS}

The CMV is the most common cause of congenital infection. Its incidence in Western countries varies from 0.18

Table 1: Frequent US and/or MRI prenatal findings in congenital infections

\begin{tabular}{|c|c|c|}
\hline Infection & CNS findings & Other findings \\
\hline Cytomegalovirus & $\begin{array}{l}\text { Periventricular/parenchymal calcifications, lenticulostriatal } \\
\text { vessel calcifications, retinal calcifications, hydrocephalus, } \\
\text { microcephaly, lissencephaly, polymicrogyria, pachygyria, } \\
\text { cerebellar aplasia, periventricular leukomalacia, } \\
\text { Schizencephaly }\end{array}$ & $\begin{array}{l}\text { Placental calcifications, liver or heart calcifications, } \\
\text { hepato/splenomegaly, bowel hyperechogenicity, } \\
\text { AF abnormalities, hydrops, IUGR, fetal death }\end{array}$ \\
\hline Rubella & $\begin{array}{l}\text { Microcephaly, encephalocele, anencephaly, intracranial } \\
\text { calcifications, ocular defects }\end{array}$ & $\begin{array}{l}\text { Micrognathia, cleft palate, placental calcifications, } \\
\text { liver calcifications, congenital heart defects, IUGR }\end{array}$ \\
\hline Varicella & Intracranial, retinal calcifications, microcephaly & $\begin{array}{l}\text { Placental calcifications, segmental limb } \\
\text { hypoplasia, IUGR }\end{array}$ \\
\hline HSV & Intracranial, retinal calcifications, cerebral atrophy & Placental calcifications, liver calcifications, IUGR \\
\hline Zika virus & $\begin{array}{l}\text { Microcephaly, hydrocephalus, corpus callosum hypoplasia, } \\
\text { mega cisterna magna, gyration abnormalities, cerebellar } \\
\text { dysplasia, periventricular/parenchymal calcifications, } \\
\text { microphthalmia }\end{array}$ & IUGR \\
\hline Syphilis & Intracranial, retinal calcifications & $\begin{array}{l}\text { Placental, liver, heart calcifications, bone } \\
\text { deformities, IUGR, hydrops, fetal death }\end{array}$ \\
\hline PVB19 & & Increased NT, hydrops, fetal death \\
\hline $\begin{array}{l}\text { Coxsackie virus } \\
\text { (B1, B5) }\end{array}$ & Intracranial calcifications, cerebral atrophy & Liver, heart, kidney calcifications, fetal death \\
\hline HIV & Intracranial calcifications (basal ganglia) & IUGR \\
\hline Tuberculosis & Intracranial calcifications & $\begin{array}{l}\text { Hepato/splenomegaly, placental, liver, kidney } \\
\text { calcifications, bowel hyperechogenicity, bone } \\
\text { deformities, fetal death }\end{array}$ \\
\hline Listeriosis & Intracranial calcifications & Hepato/splenomegaly, hydrops, fetal death \\
\hline Gonorrhea & Intracranial, ocular calcifications & IUGR \\
\hline Toxoplasmosis & $\begin{array}{l}\text { Intracranial calcifications, retinal calcifications, } \\
\text { microphthalmia, hydrocephalus }\end{array}$ & $\begin{array}{l}\text { Placental, liver calcifications, bowel } \\
\text { hyperechogenicity, hydrops, IUGR, fetal death }\end{array}$ \\
\hline Malaria & & Placental calcifications, hydrops \\
\hline Trypanosomiasis & Intracranial calcifications & $\begin{array}{l}\text { Placental, liver calcifications, hydrops, IUGR, fetal } \\
\text { death }\end{array}$ \\
\hline Fungal infections & Ventriculomegaly & $\begin{array}{l}\text { Placental calcifications, umbilical cord } \\
\text { abnormalities, fetal death }\end{array}$ \\
\hline
\end{tabular}

NT: Nuchal translucency 
Table 2: The US findings in congenital infections more frequently associated with CNS anomalies

\begin{tabular}{ll}
\hline Finding & Infections \\
\hline Intracranial calcifications & CMV, toxoplasmosis, rubella, VZV, HSV, syphilis, HIV, Listeria, gonorrhea, tuberculosis, \\
& malaria, Coxsackie virus, Zika virus, trypanosomiasis, schistosomiasis \\
Hydrocephalus & CMV, toxoplasmosis, rubella, HSV, syphilis, tuberculosis, trypanosomiasis, schistosomiasis \\
Microcephaly & CMV, Zika virus, rubella, VZV, HSV, syphilis, toxoplasmosis, tuberculosis, trypanosomiasis, \\
& schistosomiasis \\
Cerebral atrophy & Rubella, CMV, toxoplasmosis, HSV, syphilis, tuberculosis, trypanosomiasis, schistosomiasis \\
Neuron migration abnormalities & CMV, Zika virus \\
Ocular abnormalities & Toxoplasmosis, rubella, CMV, VZV, HSV, syphilis, gonorrhea, tuberculosis, Zika virus \\
\hline
\end{tabular}

In bold: More relevant associated infections

to $2.4 \%,{ }^{4,5}$ being an average of $0.7 \%,{ }^{6}$ while in developing countries, it is probably much higher. ${ }^{7}$ In Italy, approximately 5,500 infected newborns are expected each year ${ }^{8}$ and about $11.9 \%$ of women with a primary infection elect to terminate the pregnancy. ${ }^{9}$ Vertical transmission following primary infection in pregnancy occurs in about $30 \%$ of cases ${ }^{10}$ and it is higher at more advanced GA. Nonprimary maternal infections (re-infections or re-activations) are responsible for more than half of congenital CMV cases in high seroprevalence regions, but their vertical transmission occurs only in about $1 \%$ of cases. Approximately $15 \%$ of infected infants develop the classical congenital CMV syndrome, ${ }_{1}^{11}$ which includes IUGR, microcephaly, hepatosplenomegaly, petechiae, jaundice, chorioretinitis, thrombocytopenia, and anemia and has high mortality and high risk of serious neurologic sequelae. ${ }^{12,13}$ About $25 \%$ of the asymptomatically infected infants develop later in childhood potentially disabling sequelae, most commonly SNHL. ${ }^{14-16}$ To date, no vaccine has been approved for primary prevention of infection, no therapy has been approved, neither for prevention of vertical transmission nor for prenatal treatment of infected fetuses, and no therapy is available for treatment of asymptomatic infected infants at risk of developing sequelae. The global impact of the infection is high and the only effective measures in reducing it are maternal hygienic efforts to avoid infection in pregnancy and treat with antiviral drugs, the symptomatically infected infants.

In hematogenous (transplacental) CMV infections, virtually any fetal cell can be infected and almost any cell type has been described to carry the characteristic viral inclusions. Inflammation is prominent and probably causes most of the subsequent damages, with the aspect on CNS of a focal encephalitis and periependymitis. It is difficult to predict severity of the neurologic outcome and it does not appear to be related to viral load on AF. In symptomatic infants, the most common CNS findings are not only motor disorder, cognitive delay, and epilepsy, but also long-term effects on neurocognitive development.

Most brain lesions are detected in the periventricular zone, probably due to a particular tropism of the virus for these regions or the spread through the ventricular system as a preferential way. Disruption of glia limitans contributes to ventricle enlargement. When acute flogosis resolves, gliosis and calcifications are left. As expected from pathology, the most common US findings are periventricular calcifications, ventriculomegaly (VM), loss of white/gray matter demarcation, and microcephaly. Anatomic fetal damage is more likely for early infections, so US findings are detected in $26 \%$ of the cases with maternal infection before 20 weeks of GA, as opposed to $6.2 \%$ after 20 weeks of GA. ${ }^{17}$ Most common US findings in CMV congenital infection are shown in Table $3{ }^{18}$

Calcifications are typical, but not pathognomonic; they are typically periventricular and punctiform, in the ependymal or subependymal region. Spots of calcification in the basal ganglia, white matter, or cortex may occur and are often asymmetrical. The association of these features with patchy white matter abnormalities, cortical malformations, and anterior temporal cystic abnormalities is the most suggestive finding of CMV. The periventricular hyperechogenicity are not true calcifications when observed prenatally, maybe because they represent evolving micro-abscesses, ${ }_{1}^{19}$ which calcify only later. Differential diagnosis for intracranial calcifications must include congenital infections, intracranial hemorrhage, intracranial teratoma, and tuberous sclerosis. Other infective causes

Table 3: Common US findings in congenital CMV infection

\begin{tabular}{ll}
\hline Finding & Frequency (\%) \\
\hline Intracranial calcifications & $0.6-17.4$ \\
Microcephaly & 14.5 \\
Echogenic bowel & $4.5-13$ \\
IUGR & $1.9-13$ \\
Subependymal cysts & 11.6 \\
Ventriculomegaly & $4.5-11.6$ \\
Ascites & 8.7 \\
Pericardial effusion & 7.2 \\
Hyperechogenic kidneys & 4.3 \\
Hepatomegaly & 4.3 \\
Placentitis & 4.3 \\
Hepatic calcifications & 1.4 \\
Hydrops & 0.6 \\
\hline
\end{tabular}


of calcifications are Toxoplasma, HSV, varicella, parvovirus, HIV, and lymphocytic choriomeningitis. The CMV, the most common cause of congenital infection, is also the first infectious etiology of intracranial calcifications in infants, reported in 30 to $90 \%$ of cases, ${ }^{20}$ but they are very common also in congenital toxoplasmosis, in 50 to $80 \%$ of cases. ${ }^{21,22}$

Ventricular space enlargement in CMV infection is another common finding. Ventriculomegaly has different definitions, the most used of which is the enlargement of the width of the atria (AW) of the lateral ventricles $>10 \mathrm{~mm}$, which is 4 standard deviation (SD) greater than the mean. ${ }^{23}$ The AW have to be measured on an axial plane at the level of the thalami by positioning calipers on the internal margins of the ventricular wall, perpendicular to the long axis of the ventricles. The VM is defined as mild, with an $\mathrm{AW}$ from 10 to $12 \mathrm{~mm}$, moderate from 12.1 to $14.9 \mathrm{~mm}$, and severe if greater than $15 \mathrm{~mm} .{ }^{24}$ Congenital infections, particularly by CMV and Toxoplasma, may cause hydrocephalus, but their contribution to the total burden of VMs is low and possibly underestimated. ${ }^{25}$ In an old series, $5 \%$ of the hydrocephalus had an infectious cause. ${ }^{26}$ When VM is diagnosed, serologic screening is important along with fetal MRI and genetic tests, in selected cases. Screening in Western countries must include CMV, HSV1 and HSV2, Toxoplasma, Rubella, PVB19, Epstein-Barr virus, and Enteroviruses. ${ }^{27}$ The VM in CMV infection is typically due to periventricular tissue destruction, so it is not high pressure. Also, MCA resistance index is not increased, in contrast to high-pressure obstructive hydrocephalus. ${ }^{28}$ The VM and intracranial calcifications in a CMV-infected fetus are shown in Figure 1.

Microcephaly is defined as a head circumference (HC) more than $3 \mathrm{SD}$ below the GA mean. It is more often diagnosed at birth and, to detect it with more sensitivity, a prenatal US transvaginal sonography may be better in cephalic fetuses, according to some authors. A Doppler study may be beneficial, showing decreased blood flow in small cerebral hemispheres. ${ }^{29}$ Differential diagnosis of microcephaly must include other infections, constitutional microcephaly, genetic syndromes, abnormal karyotype, neural tube defects, hypoxic insult, and monochorionic twin complications. ${ }^{30}$ In CMV infection, microcephaly may be a very early sign, while constitutional cases appear only later. ${ }^{31}$ In a study on seriously damaged CMV-infected fetuses, microcephaly was common, and its presence correlated with the density of cells infected by the virus and cortical abnormalities at histology. ${ }^{32}$

White matter abnormalities are typical of CMV too. They are usually patchy and often asymmetrical, with areas of normal myelination within the abnormal white matter. Temporal cysts and temporal lobe swelling have also been described, but may be related to congenital Rubella as well. ${ }^{33}$ Periventricular echogenic halo, defined as bilateral areas of homogeneous increased echogenicity of the parenchyma surrounding the ventricular margins with well-defined borders, observable at 20- to 22-week scan, has recently been reported as a sign suggestive of fetal infection. It is associated with white matter lesions and telencephalic leukoencephalopathy demonstrable at pathological studies. ${ }^{34}$

The CMV also causes thrombocytopenia, so interventricular or intracranial hemorrhages may be a complication; they can progress to porencephaly. Fetal regional medical imaging (RMI) can add more anatomical details in these cases. ${ }^{35,36}$

Influences of CMV on the developing brain have been hypothesized, such as interference with normal radial neuronal migration, leading to pachygyria, cerebellar hypoplasia, and, less frequently, to corpus callosum agenesis/hypoplasia or even lissencephaly. This damage may reflect infection of radial glia, which guides neuronal migration until 25 weeks, or may be cytokine-mediated. A recent study ${ }^{32}$ has focused on temporal cortex damage, in particular to hippocampus where atrophy, cell loss, and dyslamination have been observed. In this area, neurogenesis occurs until late, until adult life, and this may
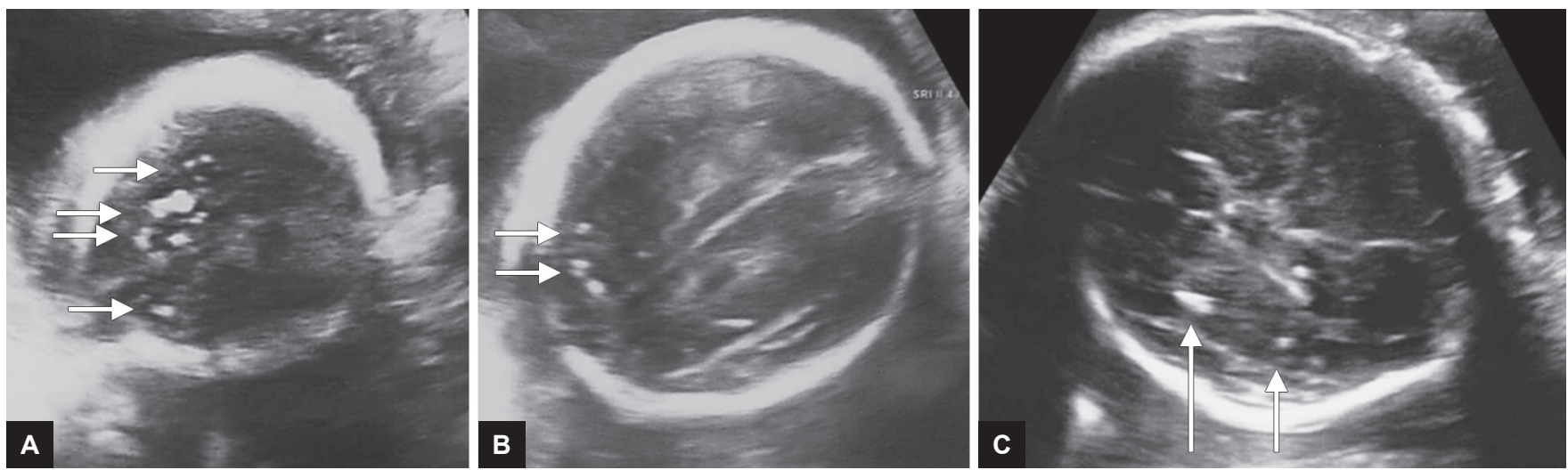

Figs $1 \mathrm{~A}$ to C: Congenital CMV infection; Intracranial calcifications (arrows) at (A and B) 25 weeks; and (C) 33 weeks 
account for important neurodevelopmental damage also after a late infection and in absence of histologic damage in other cortical areas. Temporal cortex and hippocampal damage may be studied with MRI better than with US, and may be a possible prognostic factor for neurodevelopmental outcomes. The most severe neuron migration disorder is schizencephaly, defined as a congenital clefts of the cerebral mantle extending from the pial surface to the lateral ventricles and lined by polymicrogyric cortex. It has a wide spectrum of anatomical presentations, ranging from small, unilateral fused-lip clefts to large, bilateral open lips. Its onset is presumed to occur no later than the third month of gestation, and has been reported only in a few cases of CMV infections. ${ }^{37}$

Other less common CNS findings in CMV infections are mega cisterna magna, vermian defects, intraventricular adhesions, periventricular pseudocysts, and thalamic hyperechogenicity secondary to vasculitis, which is commonly referred to as the "candlestick sign," which may be better visualized at postnatal transfontanellar US. This sign is typical of CMV infection, but has been reported in congenital toxoplasmosis too. ${ }^{38}$ Choroid plexus cyst has been considered a sign of infection, but none of the fetuses in which this marker was detected had infection at birth: This confirms the mostly benign nature of this finding. ${ }^{39-41}$

Eye may be affected by CMV, but retinal or lens calcifications are poorly detectable in utero by US. Chorioretinitis may be visualized as an echogenic lining to the vitreous body (Fig. 2). ${ }^{42}$ Also, microphthalmia has been reported, but ocular findings are more frequent in congenital Rubella and in congenital toxoplasmosis.

According to the Società Italiana di Ecografia Ostetrica e Ginecologica (SIEOG) guidelines, ${ }^{43}$ fetal MRI is indicated in any confirmed fetal infection and may add important information for the prognosis, particularly by identifying abnormal gyration, cerebellar hypoplasia, or abnormal signal in white matter. ${ }^{44}$ In a small recent study, MRI did not add any information in fetuses with normal US, but it detected cerebral abnormalities not seen at US in fetuses with either extracranial or intracranial abnormalities at US. ${ }^{45}$

A number of extracranial nonspecific signs of infection has to be carefully searched for and their presence can strengthen the suspicion of fetal infection. Placental signs are calcifications, increased thickness, and irregular echogenicity. Placental thickness should be measured in the midportion, near cord insertion. An anterior placenta thicker than $33 \mathrm{~mm}$ and a posterior placenta thicker than $40 \mathrm{~mm}$, in the second trimester, can be considered altered. It has been reported up to $30 \%$ of CMV infections, ${ }^{42}$ but in many cohorts, it is much rarer. This nonspecific marker can occur also in diabetes and it is particularly increased in congenital syphilis and in fetal hydrops. Extravillous calcifications are a common sign in term pregnancies, while intravillous calcifications raise the suspect of placentitis, but may also be present in noninfected women smokers. ${ }^{46}$ Fetal intra-abdominal echogenic foci, liver calcifications, and increased bowel thickness are other nonspecific signs of infection. Bowel hyperechogenicity is the most common extracranial sign of CMV infection, but it is very common in other conditions $(4 \%$ of all pregnancies) and may also be due to intra-amniotic hemorrhage, chromosomal abnormality, cystic fibrosis, IUGR, bowel obstruction, and even can be present in uncomplicated pregnancies. It is advisable to consider only relevant 2 nd or 3rd degree hyperechogenicity, that means, an echogenicity equal to or greater than the bone density. It is usually transient and disappears in the third trimester. Infection, mainly from CMV, is present in only $2.8 \%$ of hyperechogenic bowel fetuses due to viral enterocolitis. ${ }^{4-49}$ Extracranial findings in a CMV-infected fetus are shown in Figure 3.

Regression of some US features of infected fetuses has been documented in a few cases treated with anti-CMV hyperimmune globulins or valacyclovir investigational treatments, which have shown promising results. ${ }^{50-52}$

Any US sign is detected overall in less than $25 \%$ of CMV-infected fetuses, and in most series, the detection
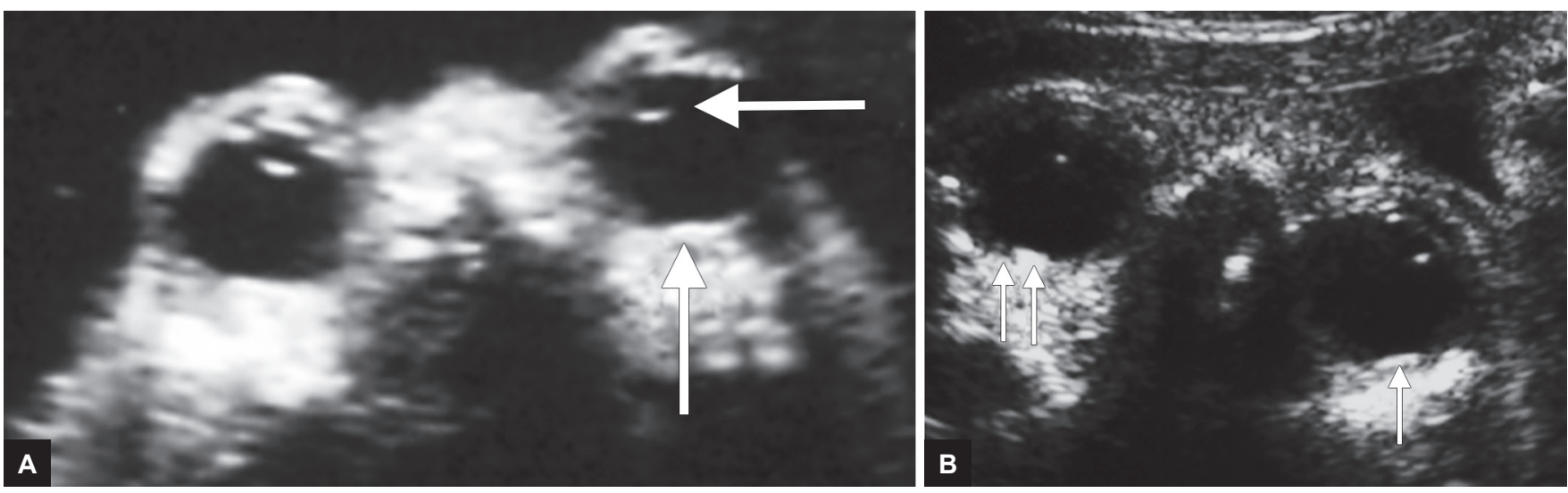

Figs 2A and B: Fetal Eyes: (A) Normal Retina, Choroid and Lens (arrows); (B) CMV infection, 32 weeks. Thickening of Choroid and Retina (arrows). 


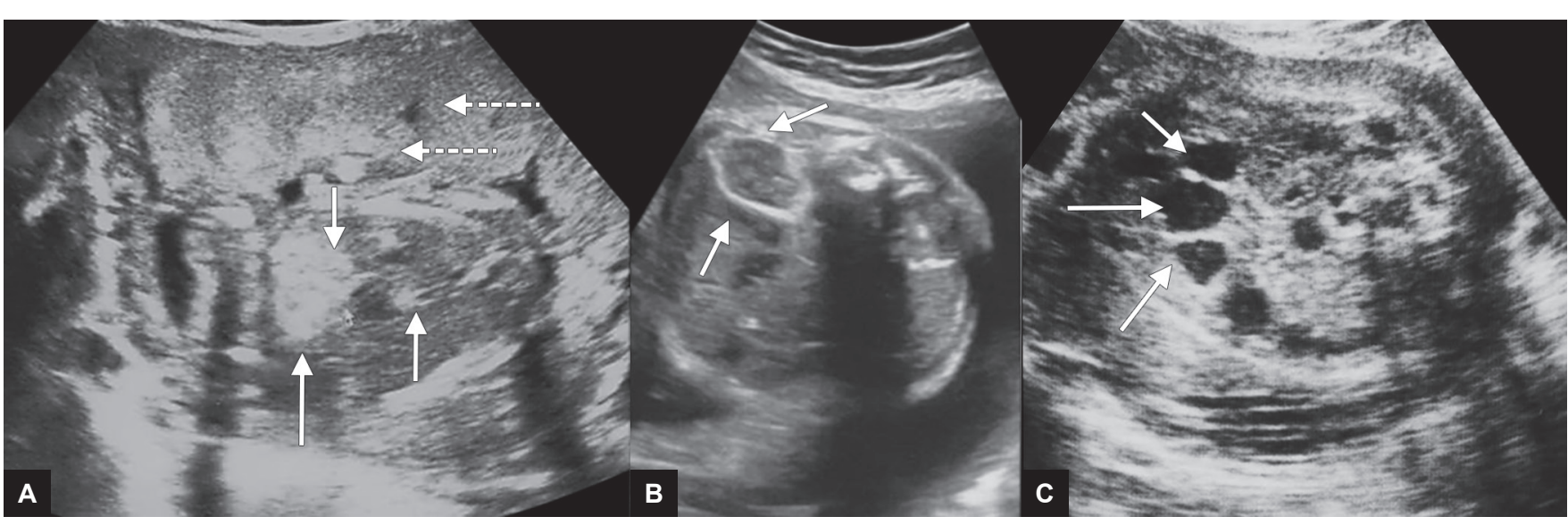

Figs 3 A to C: Congenital CMV infection, Extracranial findings. Placental disomogeneity (black arrows) and abdominal calcifications (white arrows) at 20 weeks (A). Perinephritis (arrows) at 20 weeks (B). Bowel dilation (arrows) at 25 weeks (C).

rate ranges between 9.1 and $21.5 \% .^{17,39,53-55}$ Furthermore, even if most abnormalities can be detected during a routine midtrimester scan, about a third become evident only during the third trimester. ${ }^{56}$ Microcephaly becomes more evident with the increase in growth and hydrocephalus may develop in the third trimester, when physiologic liquor production increases. In counseling, it has to be stressed that we cannot rely on US only to rule out fetal infection and that invasive diagnosis is much more reliable, with a sensitivity above $90 \% .{ }^{57}$ However, it must be considered that AF diagnosis can have false negative results and that its positivity expresses fetal infection, but not fetal damages and, indeed, the majority of infected fetuses are asymptomatic at birth.

Another critical issue is to relate CNS US findings to neonatal neurodevelopmental outcomes; in particular, SNHL may appear later in infancy in an infected infant asymptomatic at birth and is usually progressive. However, a large series has recently estimated a specificity for any US sign, either intracranial or extracranial, of $93.57 \%$ in predicting symptomatic CMV infection. Sensitivity is generally low, but an optimal negative predictive value (NPV) for symptomatic infection may be achieved combining the negative US results with the negative invasive prenatal diagnosis. The combined NPVs of US and the AF viral load and that of US and FB parameters were 95 and 100\% respectively, in a large cohort. ${ }^{58}$

\section{TOXOPLASMOSIS}

Toxoplasma gondii infection is relatively common in pregnancy and, nowadays, it is possibly the most preventable cause of congenital infectious CNS defects, since some therapeutic schemes are available for infected mothers. In Italy, the incidence of primary maternal infection approaches $0.2 \%{ }^{59}$ and the incidence of congenital infection is of 1 to $2 / 10,000 .^{60}$ The rate of vertical transmission depends on GA at the time of maternal infection, ${ }^{61}$ being
$15 \%$ in the first, $44 \%$ in the second, and $71 \%$ in the third trimester. ${ }^{62}$ Congenital infection has been described also after preconceptional and periconceptional infections ${ }^{63}$ and, exceptionally, after nonprimary infection, such as reactivation and reinfection with a different strain. ${ }^{64,65}$ Congenital toxoplasmosis is often asymptomatic and the risk of symptoms at birth and in the first 3 years of life depends on the trimester of maternal infection, being $57 \%$ for infections at 4 to 7 weeks of GA, 31\% at 20 to 23 weeks, and $9.5 \%$ after 36 weeks. The most common symptoms are intracranial and ocular lesions, present overall in about $19 \%$ of infected infants. ${ }^{62}$ Typical CNS and eye damages are as described by Wolf (Wolf's triad: Hydrocephalus, intracranial calcifications, and chorioretinitis). ${ }^{66}$ Ear damage is less typical but possible, as damages to lung, liver, kidney, heart, and endocrine glands. Rarely, a disseminate infection causes fetal hydrops. Key features in the pathogenicity of the parasite are the ability to infect almost any cell, cross nonpermissive biologic barriers, and establish persistent intracellular infection. Free parasites are quickly killed by antibody and complement; however, the parasite may be spread by nucleated blood cells. Parasitemia is short, but establishment of cells infection and reservoirs for further dissemination, notably in the placenta, is quick. Adaptive immunity, particularly T CD8+ cells, can clear intracellular infection, but parasites in silent cysts are impossible to clear either for lymphocytes or antibiotics, so silent tissue cysts may survive, especially in immunologically privileged sites (placenta, retina, and CNS), until they reactivate. The parasite persists for years, so in an apparently asymptomatic infected infant, it is possible to have long-term sequelae, particularly, reactivations of latent chorioretinic infection even after 10 years of age with small peripheral field defects or loss of macular vision; bilateral blindness is rare. ${ }^{67-69}$ Ocular lesions are not easily predictable and seem to be less influenced by timing of maternal infection and by therapy than CNS damage. Host genetic and 
Fetal Central Nervous System and Infectious Diseases

epigenetic factors have been implied in pathogenesis of ocular damage $\mathrm{e}^{70}$ and microorganism factors too, making prediction of outcome difficult only based on the standard clinical and laboratory evaluation. Among microorganism factors, genotype is best understood and South American genotypes are much more virulent, in both fetuses and immunocompetent adults, than the European genotype II. In North America, macula is involved in $54 \%$ of cases, bilaterally in $41 \%$, while in Brazil, as much as 60 to $80 \%$ of the infected fetuses have relevant ocular involvement. ${ }^{71}$ In many countries, screening in pregnancy is offered on a monthly or 3-monthly testing schedule in order to start promptly a prenatal treatment to reduce the rate of vertical transmission and treat fetal infection, preventing the sequelae of congenital infection. Treatments are based on Spiramycin with the addition of PyrimethamineSulfadiazine or Cotrimoxazole in selected cases, according to different schemes. The same drugs are also used to treat infected children. ${ }^{72}$

The most detectable anatomic anomalies are seen after Toxoplasma embryopathy, so US sensitivity varies significantly depending on time of maternal infection, being $78 \%$ for first, $20 \%$ for second, and $0 \%$ for third trimester infections. ${ }^{73}$ Brain calcifications and VM are typical. Destruction of periventricular areas is prominent and tissue debris may obstruct aqueduct. Hydrocephalus is usually obstructive, involves symmetrically the three ventricles, is severe and progresses rapidly, in days or weeks. In such cases, cephalic biometry is increased, while microcephaly is rare. The US is very sensitive in detecting such liquor abnormalities, but negative US cannot reliably exclude neurologic and neurodevelopmental damage. In the literature, it is reported that fetuses with normal US may have brain substance loss at autopsy. ${ }^{74}$ Some authors, however, have recently suggested that if calcifications at prenatal US are isolated and AW is normal, the neurological prognosis may be favorable. ${ }^{75}$

Brain calcifications are reported in 6.5 to $18 \%$ of cases. They are usually smaller than $3 \mathrm{~mm}$ and multiples in periventricular, parietal, and temporal areas. It is possible to find also linear and curve calcifications, subependymal cysts, and "candlestick sign" at birth. On postnatal imaging, the presence of three or more punctate focal calcifications, abnormal density of white matter, hydrocephalus, microcephalus, and microphthalmia classifies the disease as severe. ${ }^{76}$ Postnatal improvement or disappearance of intracranial calcifications with treatment has been documented in symptomatic infected infants. ${ }^{77}$

Fetal MRI after 22 to 23 weeks of GA is recommended by SIEOG guidelines in any case of fetal infection. ${ }^{43}$

Nonspecific extracranial signs are placentitis, abdominal calcifications, echogenic bowel, hepatomegaly, ascites, pleural/pericardial effusions, anemia, and hydrops. The
Table 4: Congenital toxoplasmosis: Findings in 210 infected infants' cohort

\begin{tabular}{|c|c|c|}
\hline Finding & Frequency (\%) & N. Examined \\
\hline IUGR & 6.2 & 210 \\
\hline Birth weight <2500 gm & 3.8 & 210 \\
\hline Birth weight $2,500-3,000 \mathrm{gm}$ & 7.1 & 210 \\
\hline Hepatosplenomegaly & 4.2 & 210 \\
\hline Neonatal jaundice & 10 & 201 \\
\hline Thrombocytopenia & 1.4 & 210 \\
\hline Anemia & 4.4 & 102 \\
\hline Microcephaly & 5.2 & 210 \\
\hline Hydrocephalus & 3.8 & 210 \\
\hline $\begin{array}{l}\text { Intracranial calcifications at } \\
\text { birth (US) }\end{array}$ & 10 & 49 \\
\hline $\begin{array}{l}\text { Intracranial calcifications at } \\
\text { birth }(R X)\end{array}$ & 11.4 & 210 \\
\hline $\begin{array}{l}\text { Intracranial calcifications at } \\
\text { birth (TC) }\end{array}$ & 84 & 13 \\
\hline Hypotonia & 5.7 & 210 \\
\hline Seizures & 3.8 & 210 \\
\hline $\begin{array}{l}\text { Electroencephalogram } \\
\text { abnormalities }\end{array}$ & 8.3 & 191 \\
\hline Liquor abnormalities & 34.2 & 191 \\
\hline Psychomotor development delay & 5.2 & 210 \\
\hline Microphthalmia & 2.8 & 210 \\
\hline Unilateral chorioretinitis & 16.1 & 210 \\
\hline Bilateral chorioretinitis & 5.7 & 210 \\
\hline Strabismus & 5.2 & 210 \\
\hline
\end{tabular}

IUGR and preterm delivery are uncommon, reported in early non-II genotype infections. Frequencies of the most common signs and symptoms in a classic cohort of infected children are shown in Table $4 .{ }^{78}$ Cases of congenital toxoplasmosis with VM, meconium peritonitis, and intracranial and abdominal calcifications are shown in Figure 4.

Prenatal US correlated well with the symptomatic fetal infection, but cannot be used to evaluate the risk of transmission, while invasive prenatal diagnosis on AF shows great sensitivity and NPV. We reviewed the scans of 626 women referred to our institution. Nearly all were treated with a Spiramycin-Cotrimoxazole protocol, which has been shown to be safe and effective in two studies, ${ }^{79,80}$ using which we had low transmission and low symptomatic infection rates. We found that nonspecific extracranial US signs (bowel hyperechogenicity, increased placental thickness, placental calcifications) had a very poor correlation with infection, and no fetus with only one of these signs had confirmed infection at birth. In untreated mothers, US positivity for specific intracranial or advanced systemic disease signs (AW>10 mm, intracranial calcifications, effusions/hydrops) was correlated to symptomatic congenital infection, with a sensitivity of $70 \%$, a specificity of $100 \%$, a positive predictive value (PPV) of $100 \%$, and an NPV $85.70 \% .{ }^{81}$ In 

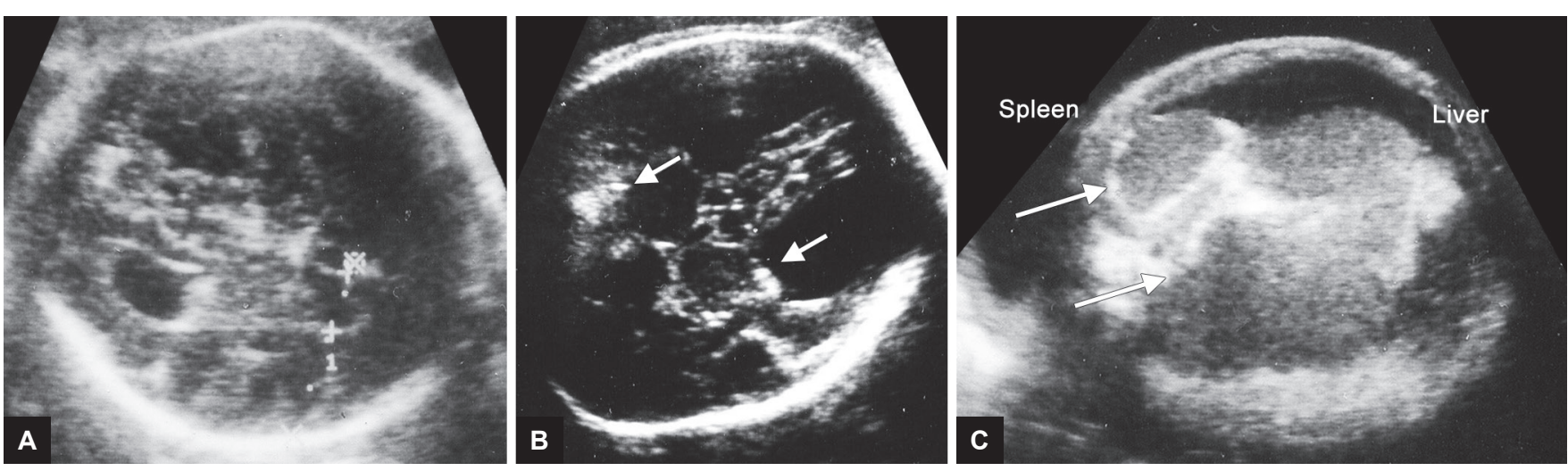

Figs 4A to C: Congenital Toxoplasmosis: Ventriculomegaly and intracranial calcifications at (A) 32 weeks; (B) 37 weeks; and $(\mathrm{C})$ meconium peritonitis and calcifications

3 out of 10 symptomatic infected infants, prenatal US was negative: One was a first trimester infection and had a late-onset chorioretinitis, another was a second trimester infection and had chorioretinitis at birth, and the last was a second trimester infection, who had right ventricular dilation and frontal horn periventricular calcifications at birth, but had normal development at 3 years follow-up.

\section{RUBELLA}

The first virus for whom teratogenicity was documented is Rubivirus. Thanks to vaccine availability, incidence of congenital rubella syndrome (CRS) has fallen dramatically, with an incidence of less than 2/100,000 live births in Europe and America, but it is still a major concern in developing countries. ${ }^{82}$ Vertical transmission rate is high, up to 12 weeks GA and decreases in second and third trimesters, as does the risk of severe fetal damages. About $50 \%$ of the infected fetuses may appear asymptomatic in utero and at birth; however, they may develop later CNS sequelae (mental retardation, microcephaly, autism) ${ }^{83,84}$ Pathogenesis is due to a particular tropism of the virus for vascular endothelial cells, so it may affect almost any organ. ${ }^{85}$ However, cardiac, ocular, and hearing defects are the most typical. The CNS damage is prominent and includes deafness and ocular defects, brain calcifications, and menigoencephalitis at birth. Ocular damage includes nuclear cataracts, microphthalmia, and pigmentary retinopathy. Possible extracranial findings in CRS are: Cardiovascular defects or myocarditis, thrombocytopenia, hepatitis, bone lesions, dental defects, hypospadias, cryptorchidism, inguinal hernia, interstitial pneumonitis, splenic fibrosis, nephrosclerosis, and nephrocalcinosis. Apart from the neurodevelopmental sequelae, lateonset endocrine dysfunction, such as insulin-dependent diabetes and thyroid dysfunctions, may affect infected children. ${ }^{83}$ As expected from the complex symptoms of CRS, US will show abnormalities in about $50 \%$ of infected fetuses, ${ }^{19}$ but cannot reliably exclude serious sequelae. Invasive prenatal diagnosis may be very helpful in this setting. ${ }^{86}$ Prenatal CNS findings at US include microcephaly, calcifications, and cysts, but also anencephaly or encephalocele. Ocular signs are difficult to be detected and, in selected cases, have to be investigated also with MRI. Extracranial signs are micrognathia, bony radiolucencies, hepatosplenomegaly, and multiple malformations. ${ }^{19}$ Other nonspecific findings are bowel hyperechogenicity, IUGR, and fetal hydrops. When US signs are present in the fetus of a woman with rubella infection in pregnancy, CRS is almost certain. ${ }^{86}$

\section{OTHER HERPES VIRUSES}

Other causes of congenital infections are VZV and HSV1 and 2.

Chickenpox (first infection with VZV) in pregnancy can cause serious complications to the woman (mainly pulmonary or cerebral) and to the fetus (congenital Varicella Syndrome-CVS). When rash develops around the time of delivery, the risk of a neonatal VZV infection with considerable morbidity and mortality is a major concern (skin lesions and pneumonia at birth), and the delivery should take place in a well-equipped center where specific hyperimmune globulins may be administered and antiviral therapy to the newborn may be started. When the virus infects the fetus during pregnancy, by transplacental route, fetal damages develop as a consequence of Herpes Zoster (reactivation), a short period after primary dissemination of the virus in an immunocompromised host. Risk of CVS is only 1 to $2 \%$ after maternal infection. ${ }^{87,88}$ A review has estimated a risk of $0.55 \%$ for infections at 2 to 12 weeks of GA, of $1.4 \%$ at 13 to 28 weeks, and $0 \%$ after 28 weeks, since CVS after third trimester infections has never been reported ${ }^{89}$ The CVS consists of skin scarring in a dermatomal distribution and hypoplasia of the limbs, microphthalmia, chorioretinitis, cataracts, microcephaly, cortical atrophy, mental retardation, dysfunction of bowel, and bladder sphincters. ${ }^{90}$ Prenatal US can detect limb defects, intracranial or abdominal calcifications, hydrocephalus, microcephaly 
and ocular abnormalities, but, due to the natural history of the disease, onset of this abnormalities is expected at least 5 weeks after maternal infection, so too early scans never detect any finding. ${ }^{91}$ Fetal MRI may add details when a fetus already shows a sign of infection. ${ }^{92}$ Even if only a minority of the infants born from mothers with primary VZV infection presents serious damages, vertical transmission rate is $20 \%{ }^{93}$ and some infants may have shingles early in infancy. Invasive prenatal diagnosis has an optimal NPV, but a lower PPV, so amniocentesis is not generally recommended and careful US has still great importance after virus detection on $\mathrm{AF}^{94}$

The HSV infection may cause neonatal infection after peripartum transmission. Some seriously infected infants have been reported to show skin lesions, other disseminate infection symptoms, and positive virology in the first 24 hours of life, so the possibility of intrauterine infection has been postulated. Fortunately, it is exceptional and in most cases is due to HSV2. A higher risk of transmission is described for infections in the first half of pregnancy and in disseminated maternal infections and, in the few cases where transmission occurs, fetal damage is almost always serious. ${ }^{95}$ Small series report a rate of symptomatic infants among the infected of $100 \% .{ }^{96}$ In congenital herpes simplex infection, ophthalmologic findings (microphthalmia, retinal dysplasia, optic atrophy, and/or chorioretinitis) and diffuse neurologic involvement (microcephaly, encephalomalacia, hydranencephaly, and/or intracranial calcification) are common along with IUGR and hepatomegaly. At birth, cutaneous manifestations include scarring, hypopigmentation and hyperpigmentation, aplasia cutis, and/or an erythematous macular exanthema. ${ }^{19,97}$

\section{ZIKA VIRUS}

An emerging infectious cause of congenital CNS defects is Zika virus. It is a flavivirus isolated for the first time in 1947, responsible for sporadic arthropod-borne infections in endemic regions, until a first major outbreak in Micronesia in 2007. Its epidemiology changed again in 2015, when about a million of new infections were reported in South America. To date, autochthonous transmission has been reported in many countries in America, including the United States. Besides mosquitoes bites (Aedes species), the virus may be transmitted by sexual contact, blood transfusion, and vertically, resulting either in a congenital or perinatal infection. ${ }^{98}$ Retrospective analyses after outbreaks in Brazil and Micronesia have shown an increase in microcephaly incidence; however, this observation has been criticized by some authors and has been attributed to notification bias, since the absolute number of cases of microcephaly reported, although much greater than in the previous years, seemed only slightly superior to the natural risk for this condition, verification on some notices showed that many cases were misdiagnosed ${ }^{99}$ and reported incidence of microcephaly in the previous year in Brazil seemed too low as compared with incidence in other countries. However, there is enough evidence to establish a relation of causality between Zika virus and CNS defects according to the principles of teratogenicity. ${ }^{100}$ Microcephaly and other CNS defects have been reported, and their incidence in fetuses of infected women has been estimated of 6 to $11 \%$. First trimester infections have a higher risk. ${ }^{101}$

The Society for Maternal-Fetal Medicine (SMFM) recommends to consider diagnosis of microcephaly certainly pathological in cases of $\mathrm{HC}>5 \mathrm{SD}$, to use a cutoff of $3 \mathrm{SD}$ to diagnose isolated microcephaly (with no other findings associated), and to perform a detailed neurosonographic examination to look for findings, such as periventricular and intraparenchymal echogenic foci, VM, cerebellar hypoplasia, and cortical abnormalities when $\mathrm{HC}$ is $>2$ SD. ${ }^{102}$ The SMFM recommends US surveillance every 3 to 4 weeks, ${ }^{102}$ while the International Society of Ultrasound in Obstetrics and Gynecology (ISUOG) recommends US every 4 to 6 weeks, underlining that 6-week interval is more likely to produce a robust diagnosis and reduce false-positive rates, but this needs to be balanced against later diagnosis. ${ }^{103}$ A systematic review showed that cutoffs of 3,4 , and 5 SDs have sensitivity respectively, of 84,68 , and $58 \%$ for $\mathrm{HC} ; 76,58$, and $58 \%$ for occipitofrontal diameter (OFD); and 94, 85, and 59\% for biparietal diameter (BPD). Specificity is higher, being respectively, of 70,91 , and $97 \%$ for $\mathrm{HC} ; 84,97$, and $97 \%$ for OFD; and 16, 46, and 80\% for BPD. The OFD and HC were better than BPD. ${ }^{104}$ Of course, accurate serological and virology diagnosis of maternal infection and exclusion of more common congenital infections is crucial, and it is recommended that samples are analyzed in a reference laboratory, since false-positive serology due to dengue virus infection is frequent. ${ }^{105}$

Besides microcephaly, other CNS abnormalities have been reported: Corpus callosus dysgenesis/agenesis, absent cavum septum pellucidum, vermian or cerebellar dysgenesis, enlarged cisterna magna, thinning of the pons and brain stem (a very unusual finding in other infections), calcifications involving cortex or white matter (particularly in frontal cortex), brain atrophy and VM (unilateral or symmetric), subependymal pseudocysts around the occipital horns, cortical abnormalities, and IUGR. ${ }^{106-108}$ Some authors comment that such severe damages involving also cerebellum, brainstem, and thalami is a distinctive feature of Zika virus infection, which seems much more destructive than typical CMV congenital infection and more similar to some reported cases of West Nile Virus intrauterine infection. ${ }^{108}$ Ocular abnormalities have 
been reported too, including focal pigment mottling and chorioretinal atrophy, optic nerve abnormalities, lens subluxation, coloboma, microphthalmia, intraocular calcifications, and cataract. Macular damage is more common with Zika virus than with other vertical infections. ${ }^{109}$ In some series, up to $42 \%$ of infected infants had at least one clinical or imaging finding, but microcephaly was present only in a minority of cases. ${ }^{110}$ Symptoms in the infant may include seizures, hearing and vision impairment, intellectual disability, and developmental impairment. Diffuse infection may be life-threatening.

\section{CONCLUSION}

Prenatal US is definitely important in the management of pregnancies complicated by maternal infection with possible vertical transmission. Although US cannot diagnose asymptomatic infections and has limitations in evaluating the sensory organs (eye, ear), it is able to identify or exclude serious fetal symptomatic infections, those which are responsible for severe handicap in postnatal life. The use of US is essential in the follow-up of fetuses proven infected at invasive prenatal diagnosis. Fetal RMI, particularly in the third trimester, can exclude or detect abnormalities of difficult US assessment, mainly in fetuses with abnormal US or with certain fetal infection (positive results of invasive diagnosis on $\mathrm{AF}$ or $\mathrm{FB}$ ).

\section{REFERENCES}

1. Robson SC, Martin WL, Morris RK. Small-for-gestational-age fetus, investigation and management (Green-top Guideline No. 31). Guidelines Committee of the Royal College of Obstetricians and Gynaecologists (RCOG), London; 2013.

2. Masini, L.; Colicchio, D.; Casarella, L.; Apicella, M. Malattie infettive e gravidanza. In: Caruso A, editor. Manuale di Ginecologia e Ostetricia. 3rd ed. Roma: CIC Ed. Internaz.; 2017. pp. 651-684.

3. Masini L, Noia G, De Santis M, Oliva N, Caruso A. Ultrasonographic findings in congenital infections. Eur J Ultrasound 1994;1(Suppl 1):S100.

4. Barbi M, Binda S, Caroppo S, Calvario A, Germinario C, Bozzi A, Tanzi ML, Veronesi L, Mura I, Piana A, et al. Multicity Italian study of congenital cytomegalovirus infection. Pediatr Infect Dis J 2006 Feb;25(2):156-159.

5. Stagno S, Reynolds DW, Huang ES, Thames SD, Smith RJ, Alford CA. Congenital cytomegalovirus infection. New Eng1 J Med 1977 Jun 2;296(22):1254-1258.

6. Dollard SC, Grosse SD, Ross DS. New estimates of the prevalence of neurological and sensory sequelae and mortality associated with congenital cytomegalovirus infection. Rev Med Virol 2007 Sep-Oct;17(5):355-363.

7. Bello C, Whittle H. Cytomegalovirus infection in Gambian mothers and their babies. J Clin Pathol 1991 May;44(5):366-369.

8. Lombardi G, Stronati M. Congenital cytomegalovirus infection. Minerva Pediatr 2005 Oct;57(5):213-227.

9. Guerra B, Simonazzi G, Banfi A, Lazzarotto T, Farina A, Lanari M, Rizzo N. Impact of diagnostic and confirmatory tests and prenatal counseling on the rate of pregnancy termination among women with positive cytomegalovirus immunoglobulin M antibody titers. Am J Obstet Gynecol 2007 Mar;196(3):221.e1-221.e6.

10. Stagno S, Pass RF, Cloud G, Britt WJ, Henderson RE, Walton PD, Alford CA. Primary cytomegalovirus infection in pregnancy: incidence, transmission to fetus, and clinical outcome. Obstet Anesth Digest 1987 Jul;7(2):46.

11. Stagno S, Whitley RJ. Herpes virus infections of pregnancy. Part I. Cytomegalovirus and Epstein-Barr virus infections. N Engl J Med 1985 Nov 14;313(20):1270-1274.

12. Stagno S, Reynolds DW, Amos CS, Dahle AJ, McCollister FP, Mohindra I, Ermocilla R, Alford CA. Auditory and visual defects resulting from symptomatic and subclinical congenital cytomegaloviral and Toxoplasma infections. Pediatrics 1977 May;59(5):669-678.

13. Lazzarotto T, Varani S, Guerra B, Nicolosi A, Lanari M, Landini MP. Prenatal indicators of congenital cytomegalovirus infection. J Pediatr 2000 Jul;137(1):90-95.

14. Fowler KB, Dahle AJ, Boppana SB, Pass RF. Newborn hearing screening: will children with hearing loss caused by congenital cytomegalovirus infection be missed? J Pediatr 1999 Jul;135(1):60-64.

15. Iwasaki S, Yamashita M, Maeda M, Misawa K, Mineta $H$. Audiological outcome of infants with congenital cytomegalovirus infection in a prospective study. Audiol Neurotol 2007;12(1):31-36.

16. Grosse SD, Ross DS, Dollard SC. Congenital cytomegalovirus (CMV) infection as a cause of permanent bilateral hearing loss: a quantitative assessment. J Clin Virol 2008 Feb;41(2):57-62.

17. Liesnard C, Donner C, Brancart F, Gosselin F, Delforge ML, Rodesch F. Prenatal diagnosis of congenital cytomegalovirus infection: prospective study of 237 pregnancies at risk. Obstet Gynecol 2000 Jun;95(6 Pt 1):881-888.

18. Society for Maternal-Fetal Medicine (SMFM), Hughes BL, Gyamfi-Bannerman C. Diagnosis and antenatal management of congenital cytomegalovirus infection. Am J Obstet Gynecol 2016 Jun;214(6):B5-B11.

19. Bailão LA, Osborne NG, Rizzi MC, Bonilla-Musoles F, Duarte G, Bailão TC. Ultrasound markers of fetal infection part 1: viral infections. Ultrasound Q 2005 Dec;21(4):295-308.

20. de Vries LS, Gunardi H, Barth PG, Bok LA, VerboonMaciolek MA, Groenendaal F. The spectrum of cranial ultrasound and magnetic resonance imaging abnormalities in congenital cytomegalovirus infection. Neuropediatrics 2004 Apr;35(2):113-119.

21. Lago EG, Baldisserotto M, Hoefel Filho JR, Santiago D, Jungblut R. Agreement between ultrasonography and computed tomography in detecting intracranial calcifications in congenital toxoplasmosis. Clin Radiol 2007 Oct;62(10):1004-1011.

22. Diebler C, Dusser A, Dulac O. Congenital toxoplasmosis. Neuroradiology 1985;27(2):125-130.

23. Cardoza JD, Goldstein RB, Filly RA. Exclusion of fetal ventriculomegaly with a single measurement: the width of the lateral ventricular atrium. Radiology 1988 Dec;169(3):711-714.

24. Kelly EN, Allen VM, Seaward G, Windrim R, Ryan G. Mild ventriculomegaly in the fetus, natural history, associated findings and outcome of isolated mild ventriculomegaly: a literature review. Prenat Diagn 2001 Aug;21(8):697-700.

25. Tully HM, Dobyns WB. Infantile hydrocephalus: a review of epidemiology, classification and causes. Eur J Med Genet 2014 Aug;57(8):359-368. 
26. Holzgreve W, Feil R, Louwen F, Miny P. Prenatal diagnosis and management of fetal hydrocephaly and lissencephaly. Childs Nerv Syst 1993 Nov;9(7):408-412.

27. Mehlhorn AJ, Morin CE, Wong-You-Cheong JJ, Contag SA. Mild fetal cerebral ventriculomegaly: prevalence, characteristics, and utility of ancillary testing in cases presenting to a tertiary referral center. Prenat Diagn 2017 Jul;37(7):647-657.

28. Bailão LA, Osborne NG, Rizzi MC, Bonilla-Musoles F, Duarte G, Bailão TC. Ultrasound markers of fetal infection, part 2: bacterial, parasitic, and fungal infections. Ultrasound Q 2006 Jun;22(2):137-151.

29. Pilu G, Falco P, Milano V, Perolo A, Bovicelli L. Prenatal diagnosis of microcephaly assisted by vaginal sonography and power Doppler. Ultrasound Obstet Gynecol 1998 May;11(5):357-360.

30. Dahlgren L, Wilson RD. Prenatally diagnosed microcephaly: a review of etiologies. Fetal Diagn Ther 2001 Nov-Dec; 16(6):323-326.

31. Bromley B, Benacerraf BR. Difficulties in the prenatal diagnosis of microcephaly. J Ultrasound Med 1995 Apr;14(4):303-306.

32. Teissier N, Fallet-Bianco C, Delezoide AL, Laquerrière A, Marcorelles P, Khung-Savatovsky S, Nardelli J, Cipriani S, Csaba Z, Picone O, et al. Cytomegalovirus-induced brain malformations in fetuses. J Neuropathol Exp Neurol 2014 Feb;73(2):143-158.

33. Livingston JH, Stivaros S, Van der Knaap MS, Crow YJ. Recognizable phenotypes associated with intracranial calcification. Dev Med Child Neurol 2013;55(1):46-57.

34. Simonazzi G, Guerra B, Bonasoni P, Pilu G, Lazzarotto T, Santini D, Rizzo N. Fetal cerebral periventricular halo at midgestation: an ultrasound finding suggestive of fetal cytomegalovirus infection. Am J Obstet Gynecol 2010 Jun;202(6): 599.e1-599.e5.

35. Nigro G, La Torre R, Sali E, Auteri M, Mazzocco M, Maranghi L, Cosmi E. Intraventricular haemorrhage in a fetus with cerebral cytomegalovirus infection. Prenat Diagn 2002 Jul;22(7):558-561.

36. Moinuddin A, McKinstry RC, Martin KA, Neil JJ. Intracranial hemorrhage progressing to porencephaly as a result of congenitally acquired cytomegalovirus infection-an illustrative report. Prenat Diagn 2003 Oct;23(10):797-800.

37. Iannetti P, Nigro G, Spalice A, Faiella A, Boncinelli E. Cytomegalovirus infection and schizencephaly. Ann Neurol 1998 Jan;43(1):123-127.

38. O'Sullivan C, Arulkumaran S, Lakasing L, Jauniaux E, Murphy K. Sequence and timing of intracranial changes in cytomegalovirus in pregnancy: a case report and literature review. Case Rep Obstet Gynecol 2017;2017:5928398.

39. Guerra B, Simonazzi G, Puccetti C, Lanari M, Farina A, Lazzarotto T, Rizzo N. Ultrasound prediction of symptomatic congenital cytomegalovirus infection. Am J Obstet Gynecol 2008 Apr;198(4):380.e1-380.e7.

40. Gupta JK, Cave M, Lilford RJ, Farrell TA, Irving HC, Mason G, Hau CM. Clinical significance of fetal choroid plexus cysts. Lancet 1995 Sep 16;346(8977):724-729.

41. Irani S, Ahmadi F, Javam M, Vosough Taghi Dizaj A, Niknejad F. Outcome of isolated fetal choroid plexus cyst detected in prenatal sonography among infertile patients referred to Royan Institute: a 3-year study. Iran J Reprod Med 2015 Sep;13(9):571-576.

42. Degani S. Sonographic findings in fetal viral infections: a systematic review. Obstet Gynecol Surv 2006;61(5):329-336.
43. Società Italiana di Ecografia Ostetrica e Ginecologica. Linee guida SIEOG ed. Cento: EDITEAM; 2015. pp. 73-89.

44. Manfredi R, Gui B, Tartaglione T, Masini L, Mirk P, Bonomo L. Fetal malformations: accuracy of MR imaging compared to sonography. RSNA Annual Meeting, Chicago, USA; 2004.

45. Picone O, Simon I, Benachi A, Brunelle F, Sonigo P. Comparison between ultrasound and magnetic resonance imaging in assessment of fetal cytomegalovirus infection. Prenat Diagn 2008 Aug;28(8):753-758.

46. Fadl S, Moshiri M, Fligner CL, Katz DS, Dighe M. Placental imaging: normal appearance with review of pathologic findings. Radiographics 2017 May-Jun;37(3):979-998.

47. Hill LM, Fries J, Hecker J, Grzybek P. Second-trimester echogenic small bowel: an increased risk for adverse perinatal outcome. Prenat Diagn 1994 Sep;14(9):845-850.

48. Masini L, Ciotti S, Casarella L, De Santis M, Cesari E, Pintus C, Manzoni C, Caruso A. Hyperechogenic fetal bowel: prenatal findings and outcome in 208 cases. 19th World Congress on Ultrasound in Obstetrics and Gynecology, (ISUOG 2009) Hamburg (Germany), 13-17 September 2009, OC 12.07, Ultrasound Obstet Gynecol 2009;34(Suppl 1):23.

49. Simon-Bouy B, Satre V, Ferec C, Malinge MC, Girodon E, Denamur E, Leporrier N, Lewin P, Forestier F, Muller F, et al. Hyperechogenic fetal bowel: a large French collaborative study of 682 cases. Am J Med Genet A 2003 Sep 1; $121 \mathrm{~A}(3): 209-213$.

50. Nigro G, La Torre R, Pentimalli H, Taverna P, Lituania M, de Tejada BM, Adler SP. Regression of fetal cerebral abnormalities by primary cytomegalovirus infection following hyperimmunoglobulin therapy. Prenat Diagn 2008 Jun;28(6): 512-517.

51. Ville $Y$, Leruez-Ville M. Managing infections in pregnancy. Curr Opin Infect Dis 2014 Jun;27(3):251-257.

52. Leruez-Ville M, Ghout I, Bussières L, Stirnemann J, Magny JF, Couderc S, Salomon LJ, Guilleminot T, Aegerter P, Benoist G, et al. In utero treatment of congenital cytomegalovirus infection with valacyclovir in a multicenter, open-label, phase II study. Am J Obstet Gynecol 2016 Oct;215(4):462.e1-462.e10.

53. Lipitz S, Achiron R, Zalel Y, Mendelson E, Tepperberg M, Gamzu R. Outcome of pregnancies with vertical transmission of primary cytomegalovirus infection. Obstet Gynecol 2002 Sep;100(3):428-433.

54. Enders G, Bäder U, Lindemann L, Schalasta G, Daiminger A. Prenatal diagnosis of congenital cytomegalovirus infection in 189 pregnancies with known outcome. Prenat Diagn 2001 May;21(5):362-377.

55. Azam AZ, Vial Y, Fawer CL, Zufferey J, Hohlfeld P. Prenatal diagnosis of congenital cytomegalovirus infection. Obstet Gynecol 2001;97(3):443-448.

56. Malinger G, Lerman-Sagie T, Watemberg N, Rotmensch S, Lev D, Glezerman M. A normal second-trimester ultrasound does not exclude intracranial structural pathology. Ultrasound Obstet Gynecol 2002 Jul;20(1):51-56.

57. Lazzarotto T, Guerra B, Lanari M, Gabrielli L, Landini MP. New advances in the diagnosis of congenital cytomegalovirus infection. J Clin Virol 2008 Mar;41(3):192-197.

58. Leruez-Ville M, Stirnemann J, Sellier $Y$, Guilleminot $T$, Dejean A, Magny JF, Couderc S, Jacquemard F, Ville Y. Feasibility of predicting the outcome of fetal infection with cytomegalovirus at the time of prenatal diagnosis. Am J Obstet Gynecol 2016 Sep;215(3):342.e1-342.e9. 
59. Billi P, Della Strada M, Pierro A, Semprini S, Tommasini N, Sambri V. Three-year retrospective analysis of the incidence of Toxoplasma gondii infection in pregnant women living in the Greater Romagna Area (northeastern Italy). Clin Microbiol Infect 2016 Jun;22(6):572.e1-572.e3.

60. Tomasoni LR, Meroni V, Bonfanti C, Bollani L, Lanzarini P, Frusca T, Castelli F. Multidisciplinary approach to congenital Toxoplasma infection: an Italian nationwide survey. New Microbiol 2014 Jul;37(3):347-354.

61. Dunn D, Wallon M, Peyron F, Petersen E, Peckham C, Gilbert R. Mother-to-child transmission of toxoplasmosis: risk estimates for clinical counselling. Lancet 1999;353(9167):1829-1833.

62. SYROCOT (Systematic Review on Congenital Toxoplasmosis) Study Group, Thiébaut R, Leproust S, Chêne G, Gilbert R. Effectiveness of prenatal treatment for congenital toxoplasmosis: a meta-analysis of individual patients' data. Lancet 2007 Jan 13;369(9556):115-122.

63. Robert-Gangneux F, Yera H, D'Herve D, Guiguen C. Congenital toxoplasmosis after a preconceptional or periconceptional maternal infection. Pediatr Infect Dis J 2009 Jul;28(7):660-661.

64. Coutinho SG, Leite MA, Amendoeira MR, Marzochi MC. Concomitant cases of acquired toxoplasmosis in children of a single family: evidence of reinfection. J Infect Dis 1982 Jul;146(1):30-33.

65. Calamy L, Goudjil F, Godineau N, Bolot P. Severe congenital toxoplasmosis secondary to toxoplasma reactivation in an HIV-infected mother. Arch Pediatr 2015 Feb;22(2):181-184.

66. Wolf A, Cowen D, Paige BH. Toxoplasmic encephalomyelitis: III. A new case of granulomatous encephalomyelitis due to a protozoon. Am J Pathol 1939 Nov;15(6):657-694.

67. Wallon M, Kodjikian L, Binquet C, Garweg J, Fleury J, Quantin C, Peyron F. Long-term ocular prognosis in 327 children with congenital toxoplasmosis. Pediatrics 2004 Jun;113(6):1567-1572.

68. Berrébi A, Assouline $C$, Bessières $M H$, Lathière $M$, Cassaing $S$, Minville V, Ayoubi JM. Long-term outcome of children with congenital toxoplasmosis. Am J Obstet Gynecol 2010 Dec;203(6):552.e1-552.e6.

69. Faucher B, Garcia-Meric P, Franck J, Minodier P, Francois P, Gonnet S, L'ollivier C, Piarroux R. Long-term ocular outcome in congenital toxoplasmosis: a prospective cohort of treated children. J Infect 2012 Jan;64(1):104-109.

70. Jamieson SE, Cordell H, Petersen E, McLeod R, Gilbert RE, Blackwell JM. Host genetic and epigenetic factors in toxoplasmosis. Mem Inst Oswaldo Cruz 2009 Mar;104(2):162-169.

71. Mets MB, Holfels E, Boyer KM, Swisher CN, Roizen N, Stein L, Stein M, Hopkins J, Withers S, Mack D, et al. Eye manifestations of congenital toxoplasmosis. Am J Ophthalmol 1997 Jan;123(1):1-16.

72. Peyron F, Wallon M, Kieffer F, Garweg J. Toxoplasmosis. In: Wilson CB, Nizet V, Maldonado YA, Remington JS, Klein JO, editors. Remington and Klein's infectious diseases of the fetus and the newborn infant. 8th ed. Philadelphia: Elsevier Saunders; 2015. pp. 949-1042.

73. Hohlfeld P, MacAleese J, Capella-Pavlovski M, GiovangrandiY, Thulliez P, Forestier F, Daffos F. Fetal toxoplasmosis: ultrasonographic signs. Ultrasound Obstet Gynecol 1991;1(4):241-244.

74. Desmonts G, Daffos F, Forestier F, Capella-Pavlovsky M, Thulliez P, Chartier M. Prenatal diagnosis of congenital toxoplasmosis. Lancet 1985 Mar 2;325(8427):500-504.
75. Dhombres F, Friszer S, Maurice P, Gonzales M, Kieffer F, Garel C, Jouannic JM. Prognosis of fetal parenchymal cerebral lesions without ventriculomegaly in congenital toxoplasmosis infection. Fetal Diagn Ther 2017;41(1):8-14.

76. McLeod R, Boyer K, Karrison T, Kasza K, Swisher C, Roizen N, Jalbrzikowski J, Remington J, Heydemann P, Noble AG, et al. Outcome of treatment for congenital toxoplasmosis, 1981-2004: the national collaborative Chicago-based, congenital toxoplasmosis study. Clin Infect Dis 2006 May 15; 42(10):1383-1394.

77. Livingston JH, Stivaros S, Warren D, Crow YJ. Intracranial calcification in childhood: a review of aetiologies and recognizable phenotypes. Dev Med Child Neurol 2014 Jul;56(7): 612-626.

78. Couvreur J, Desmonts G, Tournier G, Szusterkac M. A homogeneous series of 210 cases of congenital toxoplasmosis in 0 to 11-month-old infants detected prospectively. Ann Pediatr (Paris) 1984 Nov;31(10):815-819. (French).

79. Valentini P, Annunziata ML, Angelone DF, Masini L, De Santis M, Testa A, Grillo RL, Speziale D, Ranno O. Role of spiramycin/cotrimoxazole association in the mother-to-child transmission of toxoplasmosis infection in pregnancy. Eur J Clin Microbiol Infect Dis 2009 Mar;28(3):297-300.

80. Valentini P, Buonsenso D, Barone G, Serranti D, Calzedda R, Ceccarelli M, Speziale D, Ricci R, Masini L. Spiramycin/ cotrimoxazole versus pyrimethamine/sulfonamide and spiramycin alone for the treatment of toxoplasmosis in pregnancy. J Perinatol 2015 Feb;35(2):90-94.

81. Masini L, De Santis M, Apicella M, Noia G, Santangelo R, Speziale D, Lanzone A, Valentini P. Prenatal diagnosis by ultrasound and amniocentesis in a single center cohort of 1065 pregnancies complicated by maternal Toxoplasma infection. ISUOG 2017-27th World Congress-16-19 September, Vienna, Austria OC05.05. Ultrasound Obstet Gynecol 2017;50(Suppl 1):10.

82. Vynnycky E, Adams EJ, Cutts FT, Reef SE, Navar AM, Simons E, Yoshida LM, Brown DW, Jackson C, Strebel PM, et al. Using seroprevalence and immunisation coverage data to estimate the global burden of congenital rubella syndrome, 1996-2010: a systematic review. PLoS One 2016 Mar 10;11(3):e0149160.

83. Duszak RS. Congenital rubella syndrome-major review. Optometry 2009 Jan;80(1):36-43.

84. Hutton J. Does rubella Cause autism: a 2015 reappraisal? Front Hum Neurosci 2016 Feb 1;10:25.

85. Thompson KM, Simons EA, Badizadegan K, Reef SE, Cooper LZ. Characterization of the risks of adverse outcomes following rubella infection in pregnancy. Risk Anal 2016 Jul;36(7):1315-1331.

86. De Santis M, Cavaliere AF, Straface G, Caruso A. Rubella infection in pregnancy. Reprod Toxicol 2006 May;21(4):390-298.

87. Harger JH, Ernest JM, Thurnau GR, Moawad A, Thom E, Landon MB, Paul R, Miodovnik M, Dombrowski M, Sibai B, et al. Frequency of congenital varicella syndrome in a prospective cohort of 347 pregnant women. Obstet Gynecol 2002 Aug;100(2):260-265.

88. Enders G, Miller E, Cradock-Watson J, Bolley I, Ridehalgh M. Consequences of varicella and herpes zoster in pregnancy: prospective study of 1739 cases. Lancet 1994 Jun 18;343(8912): 1548-1551.

89. Tan MP, Koren G. Chickenpox in pregnancy: revisited. Reprod Toxicol 2006 May;21(4):410-420. 
90. Pastuszak AL, Levy M, Schick B, Zuber C, Feldkamp M, Gladstone J, Bar-Levy F, Jackson E, Donnenfeld A, Meschino W, et al. Outcome after maternal varicella infection in the first 20 weeks of pregnancy. N Engl J Med 1994 Mar 31;330(13):901-905.

91. Pretorius DH, Hayward I, Jones KL, Stamm E. Sonographic evaluation of pregnancies with maternal varicella infection. J Ultrasound Med 1992 Sep;11(9):459-463.

92. Verstraelen H, Vanzieleghem B, Defoort P, Vanhaesebrouck $P$, Temmerman M. Prenatal ultrasound and magnetic resonance imaging in fetal varicella syndrome: correlation with pathology findings. Prenat Diagn 2003 Sep;23(9):705-709.

93. Paryani SG, Arvin AM. Intrauterine infection with varicellazoster virus after maternal varicella. N Engl J Med 1986 Jun 12;314(24):1542-1546.

94. Meyberg-Solomayer GC, Fehm T, Muller-Hansen I, Enders G, Poets C, Wallwiener D, Solomayer EF. Prenatal ultrasound diagnosis, follow-up, and outcome of congenital varicella syndrome. Fetal Diagn Ther 2006;21(3):296-301.

95. Pichler M, Staffler A, Bonometti N, Messner H, Deluca J, Thuile T, Kluge R, Schmuth M, Eisendle K. Premature newborns with fatal intrauterine herpes simplex virus- 1 infection: first report of twins and review of the literature. J Eur Acad Dermatol Venereol 2015 Jun;29(6):1216-1220.

96. Hutto C, Arvin A, Jacobs R, Steele R, Stagno S, Lyrene R, Willett L, Powell D, Andersen R, Werthammer J, et al. Intrauterine herpes simplex virus infections. J Pediatr 1987 Jan;110(1):97-101.

97. Florman AL, Gershon AA, Blackett PR, Nahmias AJ. Intrauterine infection with herpes simplex virus: resultant congenital malformations. JAMA 1973 Jul 9;225(2):129-132.

98. Plourde AR, Bloch EM. A literature review of Zika virus. Emerg Infect Dis 2016 Jul;22(7):1185-1192.

99. Paixão ES, Barreto F, Teixeira Mda G, Costa Mda C, Rodrigues LC. History, epidemiology, and clinical manifestations of Zika: a systematic review. Am J Public Health 2016 Apr;106(4):606-612.

100. Rasmussen SA, Jamieson DJ, Honein MA, Petersen LR. Zika virus and birth defects—-reviewing the evidence for causality. N Engl J Med 2016 May 19;374(20):1981-1987.
101. Honein MA, Dawson AL, Petersen EE, Jones AM, Lee EH, Yazdy MM, Ahmad N, Macdonald J, Evert N, Bingham A, et al. Birth defects among fetuses and infants of US women with evidence of possible Zika virus infection during pregnancy. JAMA 2017 Jan 3;317(1):59-68.

102. Chervenak FA, Jeanty P, Cantraine F, Chitkara U, Venus I, Berkowitz RL, Hobbins JC. The diagnosis of fetal microcephaly. Am J Obstet Gynecol 1984 Jul 1;149(5):512-517.

103. Papageorghiou AT, Thilaganathan B, Bilardo CM, Ngu A, Malinger G, Herrera M, Salomon LJ, Riley LE, Copel JA. ISUOG Interim Guidance on ultrasound for Zika virus infection in pregnancy: information for healthcare professionals. Ultrasound Obstet Gynecol 2016 Apr;47(4):530-532.

104. Chibueze EC, Parsons AJ, Lopes KD, Yo T, Swa T, Nagata C, Horita N, Morisaki N, Balogun OO, Dagvadorj A, et al. Diagnostic accuracy of ultrasound scanning for prenatal microcephaly in the context of Zika virus infection: a systematic review and meta-analysis. Sci Rep 2017 May 23;7(1):2310.

105. Cordeiro MT. Zika virus: laboratory diagnosis. In: Zika in focus. Springer International Publishing; 2017. pp. 59-62.

106. Mlakar J, Korva M, Tul N, Popović M, Poljšak-Prijatelj M, Mraz J, Kolenc M, Resman Rus K, Vesnaver Vipotnik T, Fabjan Vodušek V, et al. Zika virus associated with microcephaly. N Engl J Med 2016 Mar 10;374(10):951-958.

107. Zare Mehrjardi M, Keshavarz E, Poretti A, Hazin AN. Neuroimaging findings of Zika virus infection: a review article. Jpn J Radiol 2016 Dec;34(12):765-770.

108. Oliveira Melo AS, Malinger G, Ximenes R, Szejnfeld PO, Alves Sampaio S, Bispo de Filippis AM. Zika virus intrauterine infection causes fetal brain abnormality and microcephaly: tip of the iceberg? Ultrasound Obstet Gynecol 2016 Jan;47(1):6-7.

109. Araujo AQ, Silva MT, Araujo AP. Zika virus-associated neurological disorders: a review. Brain 2016;139(8):2122-2130.

110. Brasil P, Pereira JP Jr, Moreira ME, Ribeiro Nogueira RM, Damasceno L, Wakimoto M, Rabello RS, Valderramos SG, Halai UA, Salles TS, et al. Zika virus infection in pregnant women in Rio de Janeiro. N Engl J Med 2016 Dec 15;375(24):2321-2334. 